\title{
PROFIT 'THAT IS CONDEMNED BY THE WORD OF GOD': JOHN JEWEL'S THEOLOGICAL METHOD IN HIS OPPOSITION TO USURY
}

\author{
ANDRÉ A. GAZAL* \\ Boyce College
}

\begin{abstract}
John Jewel, regarded as the principal apologist and theologian for the Elizabethan Church, was also esteemed as one of England's most important (if not the most important) authority on the subject of usury, and therefore was cited frequently by opponents of usury towards the end of the sixteenth century and throughout the seventeenth century. One of the most sustained interpretations of Jewel as a theologian on the subject of usury was by Christoph Jelinger, who observed that the late bishop of Sarum employed the same theological method in opposing usury as he did in defending the doctrines and practices of the Church of England against its Catholic opponents, that is, by appealing to the Scriptures, the Church Fathers, Church Councils, and the example of the primitive church. This article seeks to confirm the opinion of Jelinger, and in doing so show that Jewel's opposition to usury stemmed primarily from the conviction that it was both a vice and heresy that eroded the unifying attribute of Christian society which was love.
\end{abstract}

KEYWORDS: John Jewel, Usury, Theological Method, Christoph Jelinger, orthodoxy

\section{Introduction}

In a letter to Thomas Wilson, the Master of Requests, dated August 20, 1569, John Jewel (1522-71), bishop of Salisbury, enthusiastically commended him for his recent Discourse on Usury, urging him to publish it:

I have perused your learned and godly travail touching the matter of usury, M. D. Wilson, and have no doubt but, if it may please you to make it common, very much good may grow of it. Such variety of matter, such weight of reasons, such examples of antiquity, such authority of doctors both Greeks and Latins, such allegation of laws, not only civil and canon, but also provincial and temporal, such variety of cases so learnedly and so clearly answered, such eloquence, and so evident witness of God's holy will, can never possible pass in vain (Jewel 1845b: 4:1276). torical and Systematic Theology at Boyce College. Email: Andre.Gazal@ni.edu. 
Wilson did indeed publish his Discourse on Usury three years later, and in fact dedicated it to Jewel's memory. Furthermore, he affixed this letter by Jewel to the front of the work, having received it from his executor, John Garbrand, after the bishop's death. Interestingly, Peter Medine, in his biography of Thomas Wilson, makes no mention of this letter when discussing the Discourse although he does mention John Parkhurst (Medine 1986: 107). The inclusion of these to enrich the credibility of the work shows that the bishop was considered an authoritative source on the subject.

Although principally known for his Apologia Ecclesiae Anglicanae (1562) and Defence of the Apology of the Church of England (1565, 1567), John Jewel also engaged the controversial issue of usury, or the lending of money at interest. At the 1571 Parliament, Jewel served on the committee in the House of Lords which dealt specifically with the usury bill that eventually passed during this session (Institute of Historical Research 1767: 678; Jones 1989: 25). It was also at this same Parliament that Thomas Wilson participated actively in the debate concerning the same bill in the House of Commons (Institute of Historical Research 1682: 155-180). Moreover, Jewel contributed to the literature pertaining to this contentious topic in the sixteenth century. Specifically this literary input consists of an exposition of 1 Thessalonians 4:6, which is part of a larger commentary on both of Paul's epistles to the Thessalonians, originally preached as sermons at his cathedral in Salisbury either before or after the 1571 Parliamentary session, and a Latin paper on usury written in what appears to be the form of a dialogue.

Although Jewel's Commentary of St Paul's Epistles to the Thessalonians has been frequently referenced since the sermons comprising it were compiled into this volume by Garbrand, the Paper on Usury, however, has received comparatively less consideration in accounts of Jewel's thought and works. Jewel's first biographer, Laurence Humphrey (1527-90), is the first to mention the Paper on Usury, reporting that he obtained it after the bishop's death, most likely along with the volumes of Jewel's library (Humphrey, 1573: 217). Humphrey further relates that he assigned the names to the opponents arguing throughout the text. Specifically, he wrote Jewel's name above those arguments associated with the position against usury, and assigned the letters 'A. B.' to his unknown opponent: 'Annotationes quasdam, sive breves propositiones de usura, in ipsius musaeo post obitum repertas, placuit evulgare: ubi Lector intelliget ad quondam principalem quaestionem duas advesarias $\mathcal{F}^{\circ}$ acutas $\mathcal{E}^{\circ}$ succinctas responsiones. Alteri quia author est incertus, literas. A. B. apponemus, in altera erit Ioannes Iuellus' (Humphrey 1573: 217). Such editorial action and the fact that the late bishop was his patron suggest that Humphrey was quite familiar with Jewel's position on the subject. Following these comments appears the entire Paper on Usury. At the end of the dialogue, Humphrey commends Jewel's paper as having 'demonstrated more broadly and fully' the proper opinion concerning usury than 'that elegant book of Doctor Wilson's' (Humphrey 1573: 232). 
Others would share Humphrey's estimation of Jewel regarding not only general areas of divinity, but also usury.

\section{Jewel as a Theological Authority on Usury}

Throughout the last three decades of the sixteenth century and the beginning of the seventeenth century, Jewel was regarded the authoritative expositor of the doctrine of England's Protestant national church as defined by the Elizabethan Settlement. For instance, Gilbert Burnet notes that the Convocation of 1563 intended to adjoin the Apology to the Thirty-Nine Articles, and Archbishop Matthew Parker desired for the Apology to be available in cathedrals and collegiate churches as well as private houses (Burnet 1865: 3:516). Moreover, many diocesan injunctions and articles along with a myriad of parish account books together attest to the official status of the Apology and Defence of the Apology as being equal to that of the Book of Common Prayer and the Second Book of Homilies. The importance of Jewel's Apology and Defence was confirmed by the publication of them with the rest of his works in one volume by Daniel Featley (1582-1645) with official sanction in 1609 and 1611. Finally, university students at Oxford and Cambridge cited Jewel along with Calvin, Beza, Bullinger, Musculus, etc., as a major theological authority in their notebooks (Todd 1987: 56-59).

Jewel's theological authority also extended to the subject of usury. English clerical opponents of usury cited the Bishop of Salisbury as representative of the national church's position regarding usury. George Downame, for instance, in describing the injuries public sanction of usury inflicts upon the commonwealth culminating in the judgment of God, references Jewel's commentary on 1 Thessalonians alongside Martin Luther in his appeal to substantial theological authorities supporting his position (Downame 1604: 262). Moreover, Joseph Bentham (1594-1671) references Jewel as an authority on both civil and canon law when he condemns usury on legal grounds:

I am not verst in forraine Lawes, nor in the civill or Canon laws, and therefore I cannot alledge them of mine owne reading, or upon mine owne knowledge, for these therefore I depend upon, and direct you unto the rhetoricall and religious discourse of the right revered Bishop Iewel against usury, on 1 Thess 4:6 where he saith, that no good man ever used it, all that feare Gods judgements, abhorre it, He saith it is filthy gaine, a worke of darkenesse, a monster of nature, a plague of the world, and the misery of the people. Hee saith it is not of God, nor found amongst Gods children. He saith it comes from the divell, that is theft and murder. That there was never any religion, not sect, nor state, nor degree nor profession of men but have disliked it: and that all laws civill, canon, temporall and natural condemn it (Bentham 1635: 334).

Like Downame, Bentham specifically cites the late bishop's commentary on 1 Thessalonians. Specifically, in this instance, Bentham appeals to Jewel not

PERICHORESIS 13.1 (2015) 
simply as a theological but also a legal interpreter of the subject. Confessing his own ignorance of either civil or canon law, Bentham relies on the bishop as an interpreter of both types of legislation who commandingly summarizes it as condemning usury as deleterious to human society in conformity with natural law. To show that he is citing Jewel uncritically, Bentham proceeds to corroborate Jewel's pronouncement regarding the universal proscription of usury by existing law by quoting Lyndwood's Provincial (Bentham 1635: 334). Thus, Bentham treats Jewel as a source of legal opinion that is equal to an existing body of canon law that had been binding on the late medieval English church. Bentham furthermore throughout his treatise references and quotes Jewel along with other divines such as Downame and Roger Fenton to demonstrate the theological consensus of the Church of England against usury (Bentham 1635: 343, 347, 350, 353).

Among the most interesting appropriations of Jewel as a principal theological authority against usury was that by Miles Moss. In his work, The Arraignment and Conviction of Vsvrie, Moss stridently argues that usury is a violation of the commandment 'Thou shalt not steal', by referring to Jewel's interpretation of this commandment given in his commentary on 1 Thessalonians 4:6 (Moss 1595: 7). Moreover, while discussing the different definitions of usury, Moss adopts Jewel's, from the above commentary, as the best and most authoritative one (Moss 1595: 30). Moss further shows his dependence upon Jewel for his interpretation of Psalm 55.

Specifically, in this regard Moss cites Jewel equally along with specific patristic authors such as Basil, Ambrose, and Augustine, so as to suggest both continuity and equality of interpretive authority (Moss 1595: 78). The ascription of such interpretive authority to Jewel extends to Moss's description of Wilson's Discourse on Usury as containing exhaustive Scriptural discussions on the topic endorsed by the bishop (Moss 1595: 78). Most notably, Moss throughout his work refers not only to Jewel's commentary on 1 Thessalonians 4:6, but cites extensively from the bishop's Paper on Usury via Humphrey's biography (Moss 1595: 85, 94, 100, 115, 129, 136, 149, 152). Moss's work is the only sixteenth-century work which contains significant reference to Jewel's Latin paper on usury, the exploration of which will be discussed later in this work.

Throughout the seventeenth century, Jewel again figures prominently in debates concerning usury. The anonymous Death of Usury or the Disgrace of Usurers (1634) claims Jewel as an authority who agrees with him concerning his definition of ex damno habito as "when I borrow money for another and enter my bond for it, and take the like of him that receiue the mony. I may lawfully recover that I loose by the meanes of that mony' (Death 1634: 4). In the same year, John Blaxton makes frequent references to Jewel in The English Usurer, or Usury Condemned. For instance, in arguing favorably for just 
compensation by the debtor for losing money loaned to him, he cites Jewel's commentary on 1 Thessalonians (Blaxton 1634: 9). Moreover in describing the deleterious effects of usury on society, Blaxton significantly uses Jewel's similitudes in reference to usurers, treating them as authoritative descriptions of their danger to the commonwealth given by one of the Church of England's most important divines (Blaxton 1634: 52-53). Finally, Blaxton interprets Jesus' parable of the talents on the basis of Jewel's exposition given in his commentary on 1 Thessalonians, treating the late bishop as an authoritative interpreter of Scripture (Blaxton 1634: 54). Robert Bolton attacks an unidentified opponent's interpretation of Jewel as well as other divines regarding the nature the usury (Bolton 1637: 1, 5-6). Specifically, he quotes Jewel's exposition of 1 Thessalonians to prove the late bishop's and therefore the Church of England's uncompromising opposition to usury. Moreover he cites Jewel in order to corroborate the patristic consensus as well as the universal condemnation by ancient civilizations of usury (Bolton 1637: 6). Like Blaxton, Bolton quotes Jewel as an influential expositor of Scripture in explaining the classic text used for prohibiting usury, Deuteronomy 23:19: 'Thou shalt not lend upon usury to thy brother' (Bolton 1637: 41). Finally, in order to refute his opponent's construal of Jewel as an advocate of usury, Bolton expounds considerably on the bishop's distinction between an annuity intended to benefit widows and orphans and usury (Bolton 1637: 70-72).

Probably the most concentrated and sustained use of Jewel as a theological authority in the seventeenth-century debates over usury occurs in Christoph Jelinger's Usury Stated Overthrown. He quotes Jewel's definition of usury from the commentary on 1 Thessalonians as one that is authoritative (Jelinger 1670: 55-56, 123). Jelinger not only assigns this estimation to the late bishop's definition of usury, but also to his direct, graphic descriptions of its destructive effects upon Christian society (Jelinger 1670: 181). Furthermore, Jelinger specifically regards Jewel's understanding of usury as identical with those of John Calvin, Guillaume Farel, and Richard Baxter, while alleging that all of them sharply distinguished usury from partnership (Jelinger 1670: 63). At this point it should be noted that although Jelinger speaks of Jewel's views on usury as being fundamentally the same as other English bishops, he regards Jewel's discussions as the most authoritative (Jelinger 1670: 228). Not only is this indicated by the special praise he gives him, but also and probably more importantly in the greatest frequency with which he cites, references, and alludes to him, in addition to frequently quoting him against his prousury opponent. In this regard, Jelinger calls attention to the manner in which Jewel inveighed so substantially against usury:

As for the fifteen hundred years for which Bishop Jewel saith, Usury was not defended by the ancient; I would have him know, that not he only, but two or three great Divines more have asserted the same; let him bring but one Ancient Father 
or Dr. (Maniches the Heretick excepted) who has defended Usury as now it is practiced: I challenge him now to do it if he can, even Bishop Jewel challenged the Papists to prove their Religion and Opinions to have maintained in such first Centuries as he named (Jelinger 1670: 220).

In opposing usury, Jelinger employs a method admittedly identical to Jewel's which was the same the late bishop utilized against his Catholic opponents regarding the Church of Rome's doctrines and practices. He notes that Jewel inveighs against usury by appealing to the same criteria he used in impeaching the Roman Church's claim to orthodoxy: the Scriptures, the fathers, the first four general councils, and the example of the primitive church. Specifically he challenged the advocates of usury to support it by way of what we have identified elsewhere as the traditional canonical criteria for determining orthodoxy (Gazal 2014). Interestingly, Jelinger appears to be the only seventeenth-century English opponent of usury who references and cites Jewel's Latin paper on usury via Humphrey's biography (Jelinger 1670: 185).

Overall these early modern authors make this fact clear: Jewel was regarded as a significant authority concerning the issue of usury by virtue of his standing as one of the premier (if not the premier) theologians of the Church of England as well as his status as an occasional interpreter of English law concerning usury. Yet, in the polemical literature in which opponents of usury appeal to the late Bishop of Sarum frequently, the references are mostly to the commentary on 1 Thessalonians, and rarely to the Latin paper on usury. However, when mention is made of the latter, it is considerable and sustained, as evidenced in the above discussion. Among the authors referenced here, Jelinger is of most particular interest with respect to citations of the Paper on Usury.

Jelinger strongly reminded his opponent, who apparently made claims for support of usury from antiquity, to cite one orthodox authority who did, highlighting the fact that Jewel employed the same criteria for orthodoxy in condemning usury that he did in discrediting the doctrines and practices of the Catholic Church. In so doing, Jelinger was showing his audience that usury was not only a vice that irreparably harmed the economy, but tolerating and defending it was actually a form of heresy because it directly contravened the canonical criteria defining orthodox doctrine. More importantly, Jelinger appealed to the premier authority in the Church of England, who, he contended, interpreted usury the same way-as something that contradicted orthodoxy as defined by this exact same canonical criteria-the Scriptures, fathers, first four ecumenical councils, and example of the primitive church (understood as that which existed from New Testament times to the seventh century). Thus, as attested by the foremost theologian and apologist of the Church of England, usury at the very least was an aberration from the accepted doctrine of the church. 
Jelinger's reading of Jewel serves as the point of departure for this article, which will argue that the seventeenth-century divine interpreted the Elizabethan bishop of Sarum correctly with respect to the manner in which he approached the issue of usury. In his strident opposition to usury, John Jewel, as a bishop, theologian, and preacher, employed the same theological method that he utilized against the Church of Rome's claims to orthodoxy, which was to contrast them by means of the canonical criteria found in his Challenge Sermon as well as his Apology of the Church of England and Defence of the Apology of the Church of England. By applying the same method to the issue of usury, Jewel fundamentally sought to reprove it not merely as harmful vice, but as a heresy, which, if countenanced, threatened the bonds of Christian society which orthodoxy nurtured. Towards this end, we will examine Jewel's use of this method in his commentary on 1 Thessalonians 4:6 and Paper on Usury.

\section{Jewel's Theological Method in the Commentary on 1 Thessalonians 4:6}

As an exposition of a biblical passage, Jewel's remarks on usury are constructed upon the concept of the supremacy of biblical authority. Specifically, the verse in question avers: 'That no man oppress or defraud his brother in any matter; for the Lord is an avenger of all such things; as we have also told you beforetime and testified.' Jewel's purpose is to argue on the basis of this verse that usury is one of the most destructive, if not the most destructive, forms of fraud, and 'therein standeth the most miserable and shameful deceiving of the brethren' (Jewel 1845a: 2:851). From here, Jewel succinctly announces the outline of his argument: the definition of usury, the source of usury, and the consequences of usury for the commonwealth (Jewel 1845a: 2:851). Afterwards, Jewel clearly states the method by which he intends to characterize and condemn usury: 'I will declare what the holy fathers, and the apostles, and martyrs, and Christ, and God himself have thought and spoken of usury' (Jewel 1845a: 2:851). Although expressed slightly differently, Jewel will employ the same method regarding usury as he does the various doctrines over which he contends with Catholic opponents-evaluating its inherent orthodoxy, and thus legitimacy, in the light of traditional canonical criteria of the Scriptures and the fathers.

Even though in his Challenge Sermon as well as in the Apology and Defence of the Apology, Jewel explicitly names the first four ecumenical councils as well as the example of the primitive church along with the Scriptures and fathers, his proceeding discussion here will show that the bishop subsumes these two additional authorities under the designation of the fathers. This will be evident in two respects: first, like other reformers, he will cite the Scriptures and interpret them in the light of patristic tradition, which together fundamentally comprises his notion of sola Scriptura. Secondly, although he will not 
specify them, Jewel will make general statements concerning the councils and the practice of the early church which specifically appeal to their authority. Moreover, Jewel arguably regards the councils and the custom of the early church as outworkings of the principal authorities of the Scriptures and fathers, thereby deriving their status from them. Furthermore, the same general statements will show that Jewel is consciously drawing his framework respecting usury from canon law. Jewel defines usury as

a kind of lending of money, or corn, or oil, or wine, or any other thing, wherein upon covenant and bargain, we receive again the whole of the principal which we delivered, and somewhat more for the use and occupying of the same: as, if I lend 100 pound, and for it covenant to receive 105 pounds, or any other sum greater than was the sum which I did lend (Jewel 1845a: 2:851).

Upon defining usury, Jewel characterizes it as 'a kind of bargaining as all men that ever feared God's judgment have always abhorred and condemned. It is filthy gains, and a work of darkness' (Jewel 1845a: 2:851).

Jewel explicitly identifies the devil and the flesh as the source of usury. Demonstrating this on the basis of Scripture, Jewel specifically appeals to John 8:44: 'Thou art of thy father the devil, and the lust of thy father thou wilt do' (Jewel 1845a: 2:851). He then proceeds to relate this verse to the account of Satan entering Judas' heart in John 13 in order to give the spiritual pathology behind usury. Satan entered Judas' heart and thus 'put in him this greediness and covetousness of gain, for which he was content to sell his Master' (Jewel 1845a: 2:851). Immediately thereafter, the bishop succinctly describes the spiritual condition thus: 'Judas' heart was the shop: the devil was the foreman to work in it' (Jewel 1845a: 2:851). Usury, then, stems from greediness and covetousness, both of which are interrelated and initially fostered by Satan. Jewel further expands on this point by quoting 1 Timothy 6:9-10 which cites greed, or 'the desire of money' as 'the root of all evil', which leads to sundry temptations and lusts, which in turn bring one inflamed by this desire to certain hell and destruction (Jewel 1845a: 2:851).

It should be noted here that as a typical aspect of Jewel's method, he will often state his position as he does here by citing a pertinent biblical verse/passage verbatim without comment so as to represent his conviction as truly the Word of God. He quotes 1 Timothy 6:9-10 along with John 13 and 1 John 3:8 in order to assemble a coherent statement highlighting satanically induced sin as the source of usury. This last passage, which says, "whosoever committeth sin is of the devil', unambiguously punctuates the thought inferred from the preponderance of these passages: 'The devil is the planter of usury' (Jewel 1845a: 2:852). Moreover, from this collection of unified Scriptural witness Jewel constructs the diabolical process which brings usury about: 'Covetousness, desire of money, unsatiable greediness, deceitfulness, 
unmercifulness, injury, oppression, extortion, contempt of God, hatred to the brethren, and hatred of all men, are the nurses and breeders of usury' (Jewel 1845a: 2:852). Accompanying covetousness, lust, and greed are malice and hatred towards God and humanity in fostering usury. Indeed usury 'springeth from Satan, and groweth, and is watered, and fed, and nourished by these cruel and damnable monsters' (Jewel 1845a: 2:852). Usury is the fruit of covetousness, lust, greed, and hatred, all of which Satan cultivates. Usury, in essence, is satanic.

Having attributed the cause of usury to sin generated by Satan, Jewel calls attention to the results of usury. This is the longest section of the exposition, and the one to which Jewel directs patristic interpretation of Scripture. Jewel summarizes the results of usury thus:

It dissolveth the knot and fellowship of mankind: it hardeneth man's heart. It maketh men unnatural, and bereveath them of charity and love to their dearest friends. It breedeth misery, and provoketh the wrath of God from heaven. It consumeth rich men, it eateth up the poor, it maketh bankrupts, and undoeth many households. The poor occupiers are driven to flee, their wives are left alone, their children are helpless, and are driven to beg their bread, through the unmerciful dealing of the covetous usurer (Jewel 1845a: 2:852).

Usury fundamentally destroys the bond of love uniting Christian society as evidenced in the dissolution of friendships, families (specifically those of the poor), resulting in the fleeing of desperate fathers, leaving their wives and children destitute and helpless. Usury, furthermore, destroys both rich and poor and makes people bankrupt. Because it produces enmity and degradation, usury incurs divine judgment. This appraisal of the consequences of usury does not principally follow from the bishop's observation of societal estrangement, but from the declaration of Psalm 55:11: 'Usury and deceit departeth not from their streets' (Jewel 1845a: 2:852). As will also be apparent in his Paper on Usury, the unifying attribute of the Christian society is love-love which is strengthened by truth revealed by God, recorded in Scripture as interpreted by the fathers and practiced by the early church.

In keeping with his theological method, Jewel next brings patristic authority to bear on the discussion. He begins by citing Augustine who characterized usury as more cruel than theft and murder, manifesting an absence of love which obligates one to help the poor person (Jewel 1845a: 2:852). Immediately following the references to Augustine, Jewel appropriates what by this time had been regarded as highly authoritative patristic text against usury, Ambrose's commentary on the apocryphal book of Tobit (Nelson 1949: 3), where he depicts usury as giving the opposite of the relief sought by those distressed: 'He seeketh to be healed and you poison him: he asketh you bread: and you give him a knife: he desireth you to set him at liberty; 
and you bring him to further bondage' (Jewel 1845a: 2:853). He then appeals to Chrysostom who avers that usurers increase their own sins (Jewel 1845a: 2:853).

Jewel relates the custom of the early church regarding usury. In this regard, the bishop observes that the early church severely disciplined usurers by excommunicating them, prohibiting them from witnessing in court cases and making wills as well as from Christian burial (Jewel 1845a: 2:853).

Afterwards, Jewel resumes his Scriptural discussion. The passages which the bishop references explicitly condemn usury. The first of these is Luke 6:35: 'Do good and lend, looking for nothing again'. Jewel interprets this verse as telling Christians to loan freely to those in need without expecting even the principal to repaid (Jewel 1845a: 2:853). 'Defraud not another: thou wouldest not another should defraud thee. Oppress him not, have pity on this wife and children: thou wouldest not have thy wife and children undone' (Jewel 1845a: 2:853-54). Following this Jewel quotes Leviticus 25:35-36: 'If thy brother be impoverished and fallen in decay... thou shalt take no usury of him nor vantage; but thou shalt fear thy God, that thy brother may live with thee' (Jewel 1845a: 2:854). Jewel declares succinctly the meaning of this passage: 'God saith, thou shalt take no usury. And he hath power and authority to command' (Jewel 1845a: 2:854). Clearly, the bishop observes, God's Word prohibits usury. This is why it must be condemned. Following this succinct comment, Jewel cites Exodus 22:24-26: 'If thou lend money to my people, to the poor with thee, thou shalt not be as an usurer unto him: ye shall not oppress him with usury' (Jewel 1845a: 2:854). The bishop then gives pointed interpretation and application of the passage:

Shew them mercy for my sake: they are my people. I can enrich him, I can impoverish thee. I set up and throw down whom I will. When thy neighbor needeth thy help, and seeketh comfort at thy hands, afflict him not as an enemy, oppress him not like a tyrant (Jewel 1845a: 2:854).

Assuming continuity between the people of God in ancient Israel and the people of God in Christian England, Jewel maintains that the prohibition of usury is continuously normative. Just as the prohibition against usury is normative for the people of God so is the warning of divine chastisement for its allowance. To this effect, Jewel cites Ezekiel 18:13: "He that hath given forth his money upon usury, or hath taken increase, shall he live? He shall not live", saith the Lord. "He shall perish in his own sin: his blood shall be upon his head"' (Jewel 1845a: 2:854). Following this Jewel quotes and interprets what Benjamin Nelson regarded as the prime passage condemning usury, Deuteronomy 23:19: 'Thou shalt not take usury of thy brother: he is poor and fallen in decay: thou shalt not be an usurer unto him: thou shalt not oppress him with usury' (Jewel 1845a: 2:854; Nelson 1949: xix). What might 
have made the appropriation of this passage difficult for Jewel's purposes is verse 20 which allowed the Israelites to exact usury from foreigners. However, Jerome removed this hermeneutical difficulty by arguing that the later prophets and New Testament universalized this prohibition, especially the latter by including the foreigner as a brother in the people of God, particularly in its present expression, Christian society (Nelson 1949: 3-28). Jewel makes use of this interpretation in his application of the Deuteronomy passage when tells his audience that their 'brother' was specifically that one 'for whom Christ vouchsafed to shed his blood' (Jewel 1845a: 2:854). Furthermore, the brother to whom this re-interpreted passage applied was poor and had come for help (Jewel 1845a: 2:854).

Finally, Jewel makes general reference to councils supporting the prohibition of usury.

And what law doth suffer it? I trow, not the law of God; for that law straitly forbiddeth it. But what speak I of the law of God? The civil law condemneth usury, the canon law condemneth it, the temporal law condemneth it, and the law of nature condemneth it (Jewel 1845a: 2:854).

Although mentioned along with natural, temporal and civil law, canon law factors among the authorities in the criteria for orthodoxy Jewel employed. The ecclesiastical prohibitions against usury in canon law were enacted originally by the councils which Jewel regarded as among the parameters of orthodoxy, such as the Council of Nicaea in 325 (Geisst 2013: 20-21). Thus in generally asserting the prohibition of usury by all of these laws, Jewel basically acknowledges the role of the councils in defining orthodoxy. Immediately following, Jewel chides the person who insists on defending and practicing usury in opposition to of these laws, including the canon law, as one who is not a man of God (Jewel 1845a: 2:854). Given that one defending and practicing usury does so outside the parameters that Jewel identified, the offender is also guilty of heresy.

Throughout his commentary on 1 Thessalonians 4:6, Jewel clearly employs the same theological method in condemning usury as something contravening the criteria defining orthodoxy: the Scriptures, councils, fathers, and custom of the early church. The same theological method is apparent in the Paper on Usury.

\section{Jewel's Method in the Paper on Usury}

As earlier mentioned, Jewel, as bishop of Salisbury, attended this session of Parliament, and was on the Lords' committee which examined the usury bill and added to it two amendments, one of which had to do with the jurisdiction of ecclesiastical courts over usury cases (Jones 1989: 62). Given the fact that the 1571 Parliament debated the issue of usury and enacted a law prohibiting 
it, as well as Jewel's own involvement in the debate by virtue of his committee assignment, it would be plausible to infer that these together provide the context in which to interact with the contents of the Paper on Usury.

The body of the document consists of a series of exchanges between Jewel and A. B. as designated by Humphrey concerning different aspects of the issue. It begins with the question as to

Whether as a result of an agreement anything taken by him who gives money to a merchant on loan be illicit fenory [i.e. usury], even though he demand no profit nor any reward by way of profit, and it is by the merchant's own will? (Jewel 1845b: $4: 1293)$

The bishop provides the first response. He answers by asserting a significant difference between the type of contractual agreement described and usury, alleging the usurer 'also seeks gain from loss, and not just from profit' ['Imo foenerator saepe etiam ex jactura lucrum quaerit, non tantum ex lucro'] (Jewel 1845b: $4: 1293)$. From there the dialogue progresses through several specific topics regarding usury. It is at this point that $\mathrm{A}$. $\mathrm{B}$. brings up the lawfulness of any contract which endeavors to make profit, since it contradicts 'neither the first nor the second table' ['Contractum de quo quaeritur licitum puto, quia nec primae tabulae repugnant, nec secundae'] of the Decalogue (Jewel 1845b: 4:1293). This particular reply from A. B. suggests a couple of things. First, he seeks to bolster the alleged lawfulness of usury by means of a negative argument; since the Decalogue does not explicitly condemn loaning at interest, it must therefore be lawful. Secondly, this particular response by A. B., which commences a discussion regarding the place of usury in divine law, most likely says more about Jewel than this opponent since he arranged the arguments. This could suggest that Jewel's chief concern, and therefore prime objection to usury, was its clear and forthright condemnation by the Word of God. Such a contention would be consistent with his position as developed in his exposition on 1 Thessalonians 4:6 (Jewel 1845a: 2:851).

Jewel replies by denying the lawfulness of usury according to any statute, either divine or human (Jewel 1845b: 4:1293). From this assertion follows a more extensive discussion between Jewel and his opponent regarding the Scriptural prohibition of usury. A. B. further develops his contention that Scripture does not condemn loaning at interest in and of itself. Specifically, he alleges that no commandment of God explicitly proscribes the 'kind of contract in which one offers another money for his work as done in the manner of all honest trades' (Jewel 1845b: 4:1293). Moreover, he denies the distinction made by clerics and civil lawyers between those material things 'that 
are rented' and money (Jewel 1845b: 4:1293; Kerridge 2002: 10). ${ }^{1}$ To this, Jewel responds by applying both tables of the Decalogue to A. B.'s position. Because usury harms another, it violates the second table, but since both tables are inextricably connected to each other, a usurer violates simultaneously the first table, and therefore sins secretly but directly against God, the 'author of both tables' (Jewel 1845b: 4:1293). For Jewel, this is the principal grounds for the condemnation of usury as he understands it. Usury plainly violates the moral law of God summarized by the Ten Commandments. Jewel then proceeds to rebuke his opponent and others agreeing with him for refusing to defend usury biblically; he takes this as an admission that they know well that they cannot (Jewel 1845b: 4:1293).

The biblical discussion next addresses the meaning of the Hebrew word, nešek, a subject that was commonplace in contemporary discourses and debates on usury (Kerridge 2002: 26-27). Initiating this aspect of the dialogue, A. B. employs the meaning of the Hebrew word as 'bite', 'biting', or 'vexation', to highlight what he considers a very specific type of money lending the Scriptures condemn. Scripture forbids only that usury which exceeds the legal rate: 'Foenus enim (quod ab Hebraeis Nesek, id est, morsus, dicitur, et verbo Dei damnatur) tum demum exercetur, cum pecunia datur alicui mutuo, ut et sortem et aliquid supra sortem quoquo jure exigam' (Jewel 1845b: 4:1294). Jewel rebuts this interpretation by citing two passages that were common stock for those opposing usury, Psalm 15:5 and Luke 6:35 (Jewel 1845b: 4:1294). The inference Jewel draws from these passages is unambiguous: Scripture unequivocally condemns all forms of usury.

But if these and many other passages which are cited from the Word of God do not pertain to this instance, why do you not then from that same Word of God bring together those passages for usury which do pertain to this case? (Jewel 1845b: 4:1294)

By means of this rhetorical question, the frequent use of which is common in all of Jewel's polemical works, he challenges his opponent to produce any specific passages of Scripture which explicitly sanction the loaning of money at interest. To heighten the rhetorical force of this technique in this portion of the Paper on Usury, Jewel asks A. B., 'Why does it not plainly appear from the Scriptures that it is thus lawful to make an agreement with a merchant or a rich person to demand your money with usury?' (Jewel 1845b: 4:1294)

1 Such a distinction was implied in the concept of lucrum cessans or interesse lucre cessantis, i.e. 'cessant gain', whereby a lender could contract to claim losses in the event that he was either not repaid or not repaid on time thus costing him the opportunity to earn profit with that money elsewhere. However, claims to lucrum cessans could only apply to industry, agriculture, trade, land, a particular means of production, or a ship, but not to money lending.

PERICHORESIS 13.1 (2015) 
As noted above, Jewel's initial response to A. B. was that every divine and human ordinance prohibited usury. Specifically he avers: 'I, on the contrary, plainly see that usury is prohibited by all laws-divine, human, civil, canonical, new, old, Christian, and pagan-and that it is approved by no law or human ordinance' ['Ego, contra, usuram omnibus legibus divinis, humanis, civilibus, canonicis, novis, veteribus, christianis, ethnicis, video diserte prohiberi, nulla autem lege aut hominem constitutione approbari. Itaque hoc genus contractum non puto esse licitum'] (Jewel 1845b: 4: 1294). Even though in this reply Jewel includes a wider range of categories, when read in context, and compared with the discussion in the commentary on 1 Thessalonians 4:6, it strongly suggests that Jewel has in mind the Catholic tradition of the undivided church elsewhere referenced as the fathers, church councils, and the early church. The addition of the category of pagan is parallel natural in the bishop's exposition of 1 Thessalonians. As in the commentary discussed above, he cites patristic testimony by way of Chrysostom (Jewel 1845b: 4: 1294). Moreover he quotes most of the same traditional passages of Scripture mentioned in the commentary on 1 Thessalonians. However, with all of this said, Jewel's primary contention is that usury is contrary to the Word of God that is Scripture. This part of his strategy parallels that which he employed against his Catholic opponents when he challenges A. B. to produce explicit passages of Scripture which support usury. It is thus quite apparent that in the Paper on Usury makes use of the same general theological method as he does in his commentary 1 Thessalonians 4:6 as well as his polemical works against the Catholic opponents of the Elizabethan Church.

After the Scriptural discussion, the dialogue turns to the subject of the effects of usury on the commonwealth. Answering A. B.'s assertion that usury benefits the commonwealth, Jewel insists, that, on the contrary, usury causes extensive harm to the commonwealth (Jewel 1845b: 4:1294). In the final analysis, to Jewel, usury enriches no one but the usurer (Jewel 1845b: 4:129495).

Jewel's comments regarding partnerships comprise the heart of the larger discussion on contracts. In essence, for Jewel, a partnership, which he strongly advocates, is a contract in which both parties assume the same risks as well as share in the same profits (Jewel 1845b: 4:1295). The bishop juxtaposes a partnership over and against a usurious agreement in which the lender gains profit in any event regardless of the debtor's loss (Jewel 1845b: 4:1295-96). Furthermore, a partnership is a type of contract that is characteristically Christian.

The Christian is to live in this manner: moreover the Christian is to contract in this manner: for contracts and agreements are, so to speak, certain chains on human life. If a debtor says that he suffered loss through no fault of his own, the creditor therefore ought to bear the loss of his portion ['Christiani est hominis ita 
vivere; est etiam christiani hominis ita contrahere: pacta enim et convent quasi vincula quaedam sunt humanae vitae. Si debitor, inquis, nulla sua culpa jacturam quidem nullam fecerit, creditor debet ipsius etiam sortis damnum ferre'] (Jewel 1845b: 4:1297).

A distinctly Christian contract or partnership for Jewel is thus one where both parties mutually undergo all of the vicissitudes of the proposed venture.

Undergirding Jewel's view of financial transactions is an ethic founded upon the most comprehensive of Christian virtues, love. This becomes apparent towards the end of the Paper on Usury, where Jewel stresses the difference between a loan and usury. 'There is much difference between usury and a loan. For God commanded to give a loan, but prohibited usury; also a loan is conjoined with love, while usury is joined to avarice' ['Inter usuram et mutuum multum est discriminis. Deus enim mutuo dare jussit, foenerari prohibuit; et mutuum cum caritate conjunctum est, usura cum avaritia'] (Jewel 1845b: 4:1297).

This reinforces Jewel's primary objection to usury as directly contravening God's Word. At the same time, it emphasizes the only kind of monetary help specifically prescribed by Scripture in the bishop's estimation, the principal alone of which is to be repaid, as opposed to the contrary opinion maintained by A. B. which portrays lending on the condition of repayment of interest as an act of benevolence (Jewel 1845b: 4:1296-98). Thus, a loan, as Jewel would conceive of it, is a tangible expression of obedience to the divine command to love, whereas usury is a brazen demonstration of avarice. At work in this connection between a loan and love might be appropriation of an Augustinian view of love as the working out of faith. Application of such an Augustinian construct to the subject of monetary transactions seems evident in the last paragraph of the dialogue in which Jewel avers, 'for there is none other that is equal or good than the will of a good man joined with Christian love' ['Aequum enim et bonum non aliud est, quam arbitrium boni viri cum caritate christiana conjuntum'] (Jewel 1845b: 4:1298). This means then that the type of loan one makes to another evinces the nature of his love. 'For Christian love does not lend money at interest, nor does it seek the things that are its own, but those things that are Jesus Christ's' ['Caritas autem Christiana non foenerator, nec ea quae sua sunt quaerit, sed ea quae sunt Jesu Christi'] (Jewel 1845b: 4:1298). Thus, love is the distinctive characteristic of the godly loan.

Thus, Jewel's principal objection to loaning money at interest is clear. The Word of God condemns it. This position is identical to the one maintained in his commentary on 1 Thessalonians 4:6. His argument concerning the far reaching harm usury causes the commonwealth is secondary, deriving from the main objection that usury contravenes God's Word. This is largely due to the fact that Jewel formulates this position within the framework of a Respublica Christiana in which society is ideally ordered according to the Word of God. When especially a Christian commonwealth violates the clear prescrip- 
tions of God's Word by allowing open infractions to occur as a matter of common practice, it incurs destructive consequences for its citizens, and therefore ails the whole body politic. None of this, of course, originates with Jewel. The bishop of Salisbury appropriates a conception of usury, along with its supporting arguments, standard Scriptural texts, categories, and distinctions formulated mainly by Thomas Aquinas and other schoolmen, as well as canonists (Kerridge 2002: 18, 81-82; Jones 2004: 16-36).

Among the Reformers, this position would align Jewel with Luther and Melanchthon while placing him in direct odds with Reformed theologians with whom he would normally agree on most doctrinal matters, such as Bucer, Calvin, Beza, and Bullinger, whose views on interest were far more nuanced (Kerridge 2002: 23-35, 79-80, 87-112). Furthermore, the position espoused by Jewel in the Paper on Usury is virtually identical to that of Thomas Wilson's as outlined in both his Discourse as well as in his lengthy speech during the debate in the Commons concerning the usury bill (Institute of Historical Research, 1682: 155-180). A cursory examination of this debate would show that the various positions on usury (of which Wilson's was one) were disputed mostly on theological grounds (Jones 1990: 118). When considered within this particular context, especially since Jewel himself participated in the parliamentary process regarding the course of the usury bill, it becomes apparent that the position for which he argues in the Paper on Usury as well as his commentary on 1 Thessalonians 4:6 represents a position commonly shared, in this case, by members of Parliament.

This brings us now to the place of the Paper on Usury among Jewel's works and in the debate on the usury bill in Parliament. Unfortunately, at this point, the answers to both these questions are elusive. The document itself gives no explicit indication of the occasion for which Jewel composed it. Moreover, there is no reference to it in any of his extant correspondence. Neither does Humphrey, the first to mention and print the Paper on Usury, provide any information as to the reason or circumstances that prompted the bishop to author it.

\section{Conclusion}

Throughout both documents on usury, John Jewel employed the same theological method as he did in vindicating the doctrines and practices of the Elizabethan Church against its Catholic detractors-by determining illegitimacy, in this case, according to the canonical criteria of Scripture, the fathers, first four ecumenical councils, and custom of the early church. In so doing, he showed usury to be the product of deceit, greed, and hate and something that is essentially satanic. Furthermore, since Jewel in both the 1 Thessalonians commentary and the Paper on Usury is addressing those who defend usury 
in one form or another, in showing that these proponents contradict the parameters of orthodoxy. Usury, as a manifestation of hatred, destroys the bond of love that coheres a Christian society. This concept of love as the unifying attribute of a Christian commonwealth factors even more prominently in the Paper on Usury. For, it is here that the bishop of Sarum more explicitly argues that the transacting of business for worldly profit is lawful only when both parties in a contract mutually share in the fortune and loss, the lender loans freely, and all the commonwealth benefits. Such occurrences show that business is ruled by love, and therefore accords with the Word of God.

\section{Bibliography}

***** (1634) Death of Usury, or the Disgrace of Usurers. London: Robert Allott.

Bentham J (1635) The Christian Conflict: Shewing the Difficulties and Duties of this Conflict, with the Armour and Speciall Graces to be Exercised by Christian Souldiers. London: Philemon Stephens \& Christopher Meredith.

Blaxton J (1634) The English Usurer or Usury Condemned By The Most Learned and Famous Divines of the Church of England, and Dedicated to all His Majesties Subjects, For the Stay of Further Increase of the Same. London: John Norton.

Bolton R (1637) A Short and Private Discourse between M. Bolton and one M.S. concerning Usury. London: George Miller.

Burnet G (1865) The History of the Reformation of the Church of England. Oxford: Oxford University Press.

Downame G (1604) Lectures on the XV Psalm: Read in the Cathedral Church. London: Adams Flip.

Gazal AA (2014) 'A Crime Most Heinous': The Concept of Heresy in John Jewel's Apology of the Church of England. In Defending the Faith Conference, Salisbury, United Kingdom, 17 September 2014.

Geisst CR (2013) Beggar Thy Neighbor: A History of Usury and Debt. Philadelphia, PA: University of Pennsylvania Press.

Humphrey L (1573) Iohannes Iuelli Angli, Episcopi Sarisburiensis Vita. London: John Day.

Institute of Historical Research (1682) Journal of the House of Commons: April 1571. The Journals of all the Parliaments during the reign of Queen Elizabeth (accessed 5 July 2011) http://www.british-history.ac.uk/report. aspx? compid $=43684$.

Institute of Historical Research (1767) House of Lords Journal Volume 1: 30 April 1571. Journal of the House of Lords. Volume 1: 1509-1577 (1767-1830) (accessed 4 October 2011) http://www.british-history.ac.uk/report.aspx?compid $=31781$.

Jelinger C (1670) Usury Stated Overthrown Or, Usury's Champions with Their Auxiliaries Shamefully Disarmed and Beaten By An Answer to Its Chief Champion Which Lately Appeared in Print to Defend It. London: J Wright.

PERICHORESIS 13.1 (2015) 
Jewel J (1845a) Commentary of St. Paul's Epistles to the Thessalonians. In Ayre J (ed) The Works of John Jewel, 4 volumes. Cambridge: Cambridge University Press, pp. 2:813-946.

Jewel J (1845b) Paper on Usury. In Ayre J (ed) The Works of John Jewel, 4 volumes. Cambridge: Cambridge University Press, pp. 4: 1283-98.

Jones DW (2004) Reforming the Morality of Usury: A Study of the Differences that Separated the Protestant Reformers. Lanham, MD: University Press of America.

Jones NL (1989) God and the Moneylenders: Usury and Law in Early Modern England. Oxford: Blackwell.

Jones NL (1990) Religion and Parliament. In Dean DN and Jones NL (eds) The Parliaments of Elizabethan England. Oxford: Blackwell.

Kerridge E (2002) Usury, Interest, and the Reformation. Aldershot: Ashgate.

Medine P (1986) Thomas Wilson. Boston, MA: Twayne Publishers.

Moss M (1595) The Arraignment and Conviction of Vsvrie: That is, The Iniqutie, and Unlawfulness of Usurie, Displayed in Sixe Sermons, Preached at Saint Edmunds Burie in Suffolk, Upon Proverb 28:8. London: Thomas Man.

Nelson B (1949) The Idea of Usury: From Tribal Brotherhood to Universal Otherhood. Chicago, IL: University of Chicago Press.

Todd M (1987) Christian Humanism and the Puritan Social Order. Cambridge: Cambridge University Press.

Wilson T (1572) A Discourse vppon Usurye, by vvaye of Dialogue and Oracions, for the better varietye, and more delite of all those, that shall reade thys treatise. STC, 25807-403. 